\title{
Metagenomic Study of Bacterial and Archaeal Populations during Anaerobic Digestion of Lignocellulosic Waste in Lab-scale Biogas Reactors
}

\author{
Uduak U. Ndubuisi-Nnaji, Ata O. Inyang-Enin, Utibe A. Ofon and Osagie Ibhadode
}

\section{ABSTRACT}

This study evaluated using 16S rDNA gene-based metagenomics technique the populations of bacteria and archaea in digestate samples from lab-scale anaerobic bioreactors digesting pretreated and untreated coconut husk fiber, pineapple floret and banana stem. Result of biodegradability experiment indicated high microbial activity in digestate (biogas slurry), with untreated banana stem having the highest total solids (TS) and volatile solids (VS) removal efficiencies of $78.3 \%$ and $92.9 \%$ respectively. Similarly, all pretreated substrates exhibited higher TS and VS losses with corresponding TS $(77.8 \%)$ and VS $(87.2 \%)$ removal efficiencies. This TS and VS removal rates signaled increased rate of organic matter decomposition with concomitant biogas productivity. Diversity comparisons performed between samples showed rich microbial diversity in untreated sample than the pretreated sample. Taxonomic composition revealed that, for untreated samples at the phylum level, the bacterial community was predominantly Firmicutes (relative abundance 97.0\%), with $0.30 \%$ Actinobacteria and $0.10 \%$ Proteobacteria. The genus Oxobacter (35.0 \%), Clostridium (12.0 \%) and Ethanoligenens (10.0 \%) were ubiquitous and abundant in the untreated sample. The archaeal community was however dominated by the Euryarchaeota with one methanogenic order Methanomicrobiales, and a high abundance of the genera Thermacetogenium. For pretreated samples, at the phylum level, bacterial community was also dominated by Firmicutes $(95.0 \%)$, followed by Proteobacteria $(1.02 \%)$, Actinobacteria $(0.18 \%)$ and Tenericutes $(0.06$ $\%)$. The genus Clostridium (41.0 \%), Ethanoligenens $(29.0 \%)$ and Lactobacillus $(15.0 \%)$ were also ubiquitous and abundant in the pretreated sample. Archaeal community was also dominated by Euryarchaeota with the two methanogenic orders Methanomicrobiales and Methanosarcinales dominating. The major microbial groups were hydrolyzing and fermenting populations. These findings revealed rich microbial assemblage and diversity among microbial communities in biogas digestate.

Keywords: Metagenomics, anaerobic digestion, digestate, lignocellulosic biomass.

\section{INTRODUCTION}

Lignocellulosic agro-wastes comprising coconut husk fiber, pineapple floret and banana stem are abundant in nature and can serve as alternative yet sustainable energy sources. At present, anaerobic digestion (AD) has extensively been employed in the treatment and management of most biodegradable waste, namely: harvest residues, animal manures, municipal sewage sludge and kitchen waste [1]. Lab-scale anaerobic codigestion of lignocellulosic biomass has been studied in recent times [2], [3]. However, the operation of full-scale biogas plants using lignocellulosic waste as the singular and primary substrate has witnessed some serious drawbacks. The major reason
Published Online: September 13, 2020

ISSN: 2684-5199

DOI :10.24018/ejbio.2020.1.5.75

U. U. Ndubuisi-Nnaji

Department of Microbiology, University of Uyo, Akwa Ibom State, Nigeria. (e-mail: uduakndubuisi@uniuyo.edu.ng)

\section{A. O. Inyang-Enin}

Building Research Department, Nigerian Building and Road Research Institute, Abuja Nigeria.

Department of Microbiology, University of Uyo, Akwa Ibom State, Nigeria. (e-mail: inyangeninata@yahoo.com)

\section{U. A. Ofon*}

Department of Microbiology, University of Uyo, Akwa Ibom State, Nigeria. (e-mail: utibeofon @ uniuyo.edu.ng)

\section{O. Ibhadode}

Building Research Department, Nigerian Building and Road Research Institute, Abuja, Nigeria.

(e-mail: osagie.ibhadode ${ }^{\circledR}$ gmail.com)

*Corresponding Author

being that this fibrous waste (lignocellulosic biomass) is comprised of lignin, cellulose and hemicellulose, which are notably recalcitrant and difficult to degrade. Thus some labscale AD experiments have concentrated on the pretreatment of lignocellulose-containing waste (to overcome the structural complexity of lignocellulosic biomass) and codigestion with other wastes to enhance enzymatic activity on and enhance the biodegradability of cellulose among other things [3]-[5]. Nonetheless, in-depth knowledge of the microbial community involved during the anaerobic treatment of these lignocellulosic residues remains scarce.

Generation of methane from anaerobic biodegradation of lignocellulosic biomass requires the collaboration of multifarious microbial groups, comprising hydrolytic (celluloytic), saccharolytic, homoacetogenic, syntrophic 
hydrogen-producing bacteria and methanogenic archaea [6]. As a result, it thus becomes imperative to analyze and characterize the microbial community in digestate from anaerobic digesters/bioreactors with coconut husk fiber, pineapple floret and banana stem as feedstock. This will provide in-depth understanding and insight on the diverse populations of microbes involved in the AD process. This study therefore investigated the assembly of bacterial and archaeal communities in digestate samples obtained from lab-scale biogas reactors treating coconut husk fiber, pineapple floret and banana stem by $16 \mathrm{~S}$ rDNA metagenomic sequencing analysis.

\section{MAterials AND Methods}

\section{A. Source of Biogas Digestate}

Digestate samples were drawn from two (2) lab-scale anaerobic biodigesters (amber serum bottles $100 \mathrm{~mL}$ amber borosilicate glass serum bottles, Wheaton 223766, USA) digesting lignocellulosic waste. The waste biomass was subjected to wet anaerobic degradation with wash water serving as a moistening agent. The reactors were sealed using crimper with $20 \mathrm{~mm}$ aluminum cap and PTFE/Butyl septa vial headspace (Wheaton W224224, USA) for the buildup of biogas. Biogas collection was carried out according to a modified approach as described by Angelidaki et al. [7] with slight modifications. The biogas assay system was designed in a batch mode whereby the bioreactors were fed once with appropriate quantities of inoculum and feedstock [2]. The bioreactors were operated at thermophilic temperature $\left(45{ }^{\circ} \mathrm{C} \pm 2{ }^{\circ} \mathrm{C}\right)$ in a static temperature-controlled water bath for 30 days hydraulic retention time and acclimated cow manure used as microbial inoculum. The initial feedstock characteristics are presented in Table 1.

TABLE 1: BIOREACTOR COMPOSITION

\begin{tabular}{cc} 
& \multicolumn{2}{c}{ TABLE 1: BIOREACTOR COMPOSITION } \\
\hline Reactor & \multicolumn{1}{c}{ Feedstock combination $\left(\mathrm{g} \mathrm{VS}^{-1}\right)$} \\
\hline A & $\begin{array}{l}\text { 10 g each of pretreated coconut husk fibre, pineapple floret } \\
\text { and banana stem }\end{array}$ \\
B & 30 g untreated banana stem \\
\hline
\end{tabular}

The preliminary characteristics of the contents of reactor A before anaerobic digestion showed that it had a TS and VS values of $21.1 \%$ and $16.4 \%$ respectively, indicating the presence of lignin, cellulose, phenolic compounds, tannin and pectin. Consequently, the pretreated digestate after anaerobic digestion showed that the TS content and VS content reduced to $4.7 \%$ and $2.1 \%$ respectively indicating an elevated organic matter biodegradation with proportionate biogas yield. Similarly, the physicochemical characteristics of the untreated (reactor B) substrate before anaerobic digestion showed that it had a TS content of $22.1 \%$ and VS content of $6.2 \%$ indicating the presence of lignin, hemicelluloses and cellulose, in addition to ash, diethyl ether, ethanol/toluene and water at variable amounts [8]. Additionally, the untreated digestate after anaerobic digestion showed that the TS and VS contents reduced to $19.6 \%$ and $1.4 \%$ respectively also demonstrating a high organic matter degradation with corresponding biogas production. The reactor was maintained for a hydraulic retention time (HRT) of 30 days. The fermentation $\mathrm{pH}$ for untreated and pretreated digestate was 4.9 and 5.4 respectively.

The biogas digestates were washed and soaked in phosphate buffer (10 mM, pH 7.2) for 10 mins and the suspended solution was vortexed at $5000 \mathrm{rpm}$ for $10 \mathrm{~min}$. The separated pellets were obtained in the end and used for DNA extraction.

\section{B. DNA Extraction, Purification, Detection and Quantification}

The process of extracting DNA from bacterial cell involved, firstly cell lysis. To lyse a cell, the cell was cultured on a growth medium. The bacterial cells growing on the culture medium was transferred to a resuspending buffer containing lysozymes. Lysozyme is an enzyme that disrupts the bacteria cell wall. However, rapid/immediate disruption may cause some fragmentation in the chromosomal DNA; to avoid this the cells were lysed slowly with the resuspending buffer. The buffer solution contains Tris-HCl (as its main component), EDTA and sucrose. Sucrose helped to maintain the osmotic regulation of the cell so as to prevent the cell from rupturing immediately while EDTA acted as a chelating agent which chelates magnesium. The chelation of magnesium by EDTA destabilized the bacterial cell membrane because the cell membrane needs magnesium for its stability. In addition to destabilization of bacterial cell membrane, EDTA also inhibits the activities of DNAs since they also require magnesium for their activity [9].

The next step involved the addition of lysis buffer to the growing cells and disrupting slowly in the resuspending buffer. Lysis buffer contained Tris-EDTA and SDS; SDS denatures the protein present on the cell membrane thus causing it to disrupt fully. Full disruption of the cell membrane released all intracellular components into the buffer solution.

Thereafter, RNase A and Proteinase $\mathrm{K}$ were added into the buffer solution. RNase A ruptured RNAs while proteinase $\mathrm{K}$ disrupted proteins. The buffer solution containing intracellular components, DNA, ruptured RNAs and disrupted proteins was spun in a centrifuge.

Centrifugation separated the solution into pellet and supernatant. The pellet contained cell debris (cell membrane and cellular components) while the supernatant contained intracellular components (DNA, disrupted RNA and proteins).

The phenol chloroform extraction was then performed on the supernatant to separate the DNA molecule from the protein molecules by adding the supernatant to phenol chloroform in a mixing ratio of $1: 1$ and then spun in a centrifuge. This formed two layers, an upper aqueous layer consisting of DNA molecules because they are hydrophilic in nature and a lower phenol layer consisting of protein molecules because they are hydrophobic in nature.

The aqueous layer containing the DNA molecule was obtained and ideal alcohol precipitation was performed by adding 0.6 vol of isopropanol to the aqueous layer. The addition of sodium acetate (salt) to the mixture helped to reduce the hydrophilic nature of DNA thus enabling easy precipitation. This solution was centrifuged to give a pellet containing DNA precipitate contaminated with some salt. 
The salt contaminants were removed by adding $70 \%$ ethanol (iced). The chilled condition of the ethanol was needed to promote the flocculation of the DNA so they can precipitate out more easily. The salt was then taken up by the ethanol because they are more soluble in ethanol than in isopropanol. Ethanol was allowed to evaporate leaving behind only the DNA molecule. The DNA molecules were stored by adding TE (Tris-EDTA) buffer to DNA precipitate to form a DNA solution. TE buffer solubilize DNA while protecting it from degradation.

To detect and quantify the DNA, optical density (O.D) measurement and gel electrophoresis was performed. The absorbent measurement (O.D at 260nm) helped to detect DNA concentration and purity because DNA shows highest UV radiation absorbance at $260 \mathrm{~nm}$; thus, the amount of absorbance to UV radiation was directly proportional to the amount of DNA present. The standardized quantification is represented as:

\section{O.D = 50 microgram/milliliter of DNA.}

To determine the purity of the DNA, we calculated the ratio of absorbance at 260: Absorbance at 280.

$$
\text { i.e.: } \frac{A 260 \mathrm{~nm}}{A 280 \mathrm{~nm}}
$$

For a ratio between 1.6: 2.0, the DNA was considered to be pure, that is, free from contaminants such as RNA or protein.

For a ratio $<1.6$, the contaminants protein and phenol were present.

For a ratio $>2.0$, the contaminant RNA was present.

Gel electrophoresis was used to measure the presence of DNA in the purified DNA sample and the quality of purified DNA for use. In this procedure, the purified DNA was added to the agarose gel (agarose gel electrophoresis), and the presence of a DNA band became visible. A measure of the intensity of the DNA band was directly proportional to the quality of the DNA sample.

\section{Amplifying DNA with Polymerase Chain Reaction}

In order to study a gene in a double stranded DNA molecule, many copies of that particular gene must be made so as to have a large number of gene at one's disposal for a variety of experiment to be carried out. Polymerase chain reaction (PCR) is a process that allows one to amplify and make many copies of a single gene in a DNA molecule. In PCR, genes can be copied without knowing what the sequence of nucleotide in that gene is as long as the flanking sequence is known. However, without the flanking sequence the DNA primers cannot be built for the DNA replication process. The flanking sequence are found on both sides of the gene of interest; it is the segment of DNA that we do not want to replicate but know the sequence of nucleotide so as to enable us build the DNA primers that can hybridize with the flanking regions because the DNA polymerase used in PCR needs the primers for replication. There are three stages/processes involved in PCR, the three stages composed one cycle of PCR [10].

In stage one, the solution containing the double stranded DNA was heated (at $95^{\circ} \mathrm{C}$ for 15 seconds) in order to break the hybrid bond between the bases; this resulted in a separation of the double stranded DNA molecule.
Stage two involved annealing of DNA primers. This was done by cooling the heated DNA solution to a temperature of about $54{ }^{\circ} \mathrm{C}$. Since the flanking sequence was known, DNA primers were constructed that would anneal and hybridize to the 3' of the single DNA strands at the said temperature.

In stage three, a heat resistant thermophilic DNA polymerase ( $T a q$ DNA) obtained from prokaryotic cells that live in hot springs was placed into the mixture and the temperature was increased to about $72{ }^{\circ} \mathrm{C}$. The polymerase then used the primers to synthesize and replicate the complementary strand of the DNA molecule elongating from the 5' to 3' direction on both ends. Thus, after one cycle of PCR, two copies of DNA molecules were replicated. The cycle was repeated by increasing the temperature back to $95^{\circ} \mathrm{C}$.

\section{DNA Sequencing}

The sequence of nucleotides in DNA molecule gives information about how gene expression takes place and what types of proteins are produced. The method of sequencing DNA molecule employed in this study was the Sanger dideoxy method or Sanger DNA sequencing. The molecule 2' 3'-dideoxynucleoside triphosphate (ddNTP) was an important molecule in this process. The uniqueness of this molecule is that its sugar component contains a $3^{\prime}$ carbon that does not have a hydroxyl group. However, in a normal dioxynucleoside 5'-triphosphate molecule, the presence of the hydroxyl group on the 3' carbon allowed DNA polymerase to form a phospho diester bond with the next nucleotide. The absence of this hydroxyl group as in the case of ddNTP makes the molecule unable to form the phospho diester bond thereby bringing DNA replication to a halt [11].

The Sanger DNA sequencing occured in four stages. Stage one involved separation and denaturing of the double helix structure of the double stranded DNA molecule into single strands. This was done by adding sodium hydroxide $(\mathrm{NaOH})$ to the DNA solution. $\mathrm{NaOH}$ ionized the bases of the DNA molecule thus disrupting the bonds. The single stranded DNA molecule formed was then isolated by placing in DNA solution.

In stage two, the single stranded DNA molecule was replicated. This was done by using/adding a DNA primer, DNA polymerase and four types of normal dioxynucleotide 5'-triphosphate (dATP, dGTP, dCTP, TTP). The solution containing the single stranded DNA was mixed with a radioactive labelled DNA primer. The primer was needed to enable DNA polymerase initiate replication. To build the DNA primer, the initial complementary sequence on the single stranded DNA molecule was identified. For example when the initial complementary sequence was A, C, G, a primer containing the sequence $\mathrm{T}, \mathrm{G}, \mathrm{C}$ was built at the $3^{\prime}$ end of the single stranded DNA because DNA polymerase reads from $3^{\prime}$ end to $5^{\prime}$ end and builds from 5 ' end to $3^{\prime}$ end. It was important to radioactively label the DNA primer so as to identify the molecule during gel electrophoresis. Finally, a tiny amount (about 1\%) of one of the four types of ddNTP molecule was added to the solution.

Stage two was repeated three different times with the other three ddNTPs. Once the four reactions were completed, gel 
electrophoresis was performed. Each reaction mixture was placed into a lane to produce a total of four lanes. The results were transferred onto a polymer sheet which was then exposed to $\mathrm{x}$-ray autoradiography. This revealed exactly where the radioactively labelled fragments were positioned.

\section{RESUltS AND DISCUSSION}

\section{A. Phylogenies of Bacterial and Archaeal Clones Library}

Anaerobic digestion of lignocellulosic biomass to biochemical methane involves multiple steps of processes facilitated by members of bacterial and archaeal domains. The precise microbes and their metabolic activities during anaerobic degradation depend on the composition of feedstock/waste, environmental factors and operating digester conditions [12], [13]. Four sets of co-metabolically entangled microbial groups (hydrolytics, acidogens, acetogens, and methanogens) are involved in each stage of the AD process. The initial stages of $\mathrm{AD}$ yield reduced metabolic intermediates that are utilized by acid- and methane-forming bacteria [14]. Nevertheless, the association between the acetogens and methanogens is very complex since anaerobic microbiota are majorly anaerobes as oxygen causes a distressing effect through the disruption of biochemical pathways. The consequence of this effect is the oxidation of cellular factors. The current study elucidated the phylogenetic assembly of bacterial and archaeal populations in lab-scale mesophilic digestate obtained from anaerobic treatment of coconut husk fiber/pineapple floret/banana stem in biogas reactors by amplifying and sequencing a full-length $16 \mathrm{~S}$ bacterial and archaeal DNA extracted from the biogas digestate samples. Discrete $16 \mathrm{~S}$ rDNA amplicons with adequate yield for library preparation and SMRT sequencing were produced from the community samples investigated. Data analysis highlighted great diversity of microbial community members and little chimerism among the digestate samples.

From our results, bacterial domain of pretreated substrate (reactor A) had 4 distinct phyla and 14 genera were detected (Table 2 a). The archaeal domain had 1 distinct phyla with 1 genera detected. Firmicutes, Actinobacteria, Proteobacteria and Tenericutes accounted for the most abundant bacterial phyla, however about $0.1 \%$ of the phyla read was unknown. Euryarchaeota accounted for the archaeal phyla. The bacterial gene clone library displayed apparent phylogenetic diversity at the phyla and genera levels. This explained the fact that a variety of microorganisms were involved in the anaerobic digestion of the studied waste biomass. This observation was consistent with a previous finding [6].

TABLE 2 A: Phylum Classification Of Digestate From Pretreated SAMPLE (DigeSTER A)

\begin{tabular}{lcc}
\hline Phylum classification & Read count & $\%$ \\
\hline Firmicutes & 160.6 & 95.99 \\
Euryarchaeota & 44.0 & 2.63 \\
Proteobacteria & 17.0 & 1.02 \\
Actinobacteria & 3.0 & 0.18 \\
Tenericutes & 1.0 & 0.06 \\
Unknown & 1.0 & 0.06 \\
\hline
\end{tabular}

On the other hand within the domain Bacteria, of untreated substrate (reactor B), three (3) discrete phyla and over 23 genera were detected while the archaeal domain had one (1) distinct phyla with two (2) genera detected (Table 2 b). Firmicutes, Actinobacteria, Proteobacteria represented the most abundant bacterial phyla, however about $0.2 \%$ of the phyla was unknown while Euryarchaeota also represented the archaeal phyla.

TABLE 2 B: PHYLUM ClASSIFICATION OF DiGESTATE FROM UNTREATED

\begin{tabular}{lcc}
\multicolumn{3}{c}{ SAMPLE (DIGESTER B) } \\
\hline Phylum classification & Read count & $\%$ \\
\hline Firmicutes & 969.0 & 97.78 \\
Euryarchaeota & 16.0 & 1.62 \\
Actinobacteria & 3.0 & 0.30 \\
Unknown & 2.0 & 0.20 \\
Proteobacteria & 1.0 & 0.10 \\
\hline
\end{tabular}

\section{Hydrolysis}

The studied feedstock is composed of high molecular weight polymeric compounds like carbohydrates (lignocellulose, cellulose, starch), proteins (nitrogenous compounds) and lipids (oils, fats). Therefore, to access energy from these compounds, bacteria contained in inoculum enzymatically hydrolyze such complex compounds to simpler and readily available forms such as sugars, amino acids and fatty acids respectively. This process is known as hydrolysis and the process is catalyzed by an array of enzymes viz; cellulase, amylase, protease, endoglucanases and lipase [15].

So far, bulk of the cellulose-hydrolysing microbes that can utilize cellulose as the sole carbon and energy source are members of the phyla Firmicutes and Actinobacteria [16].

From the metagenomic data obtained, two groups of physiologically distinct cellulolytic bacteria were present: the aerobic and the anaerobic bacterial groups (Table 3 ). These bacterial groups differ from one another based on how they obtain energy from the sugars released from cellulose. By fermentation, Clostridia (an anaerobic bacterium) can produce from comparable quantities of glucose about $1 / 10$ of energy in the form of Adenosine triphosphate (ATP) whereas Bacillus (aerobic bacteria) do so by respiration. So, to compensate for energy (ATP) utilized during the production of glucose from cellulose, the enzymes must be ten times active [17].

\section{Acidogenesis}

This is otherwise regarded as the fermentation stage during which soluble compounds produced in the course of hydrolysis (of sugar and amino acids) are degraded and converted into $\mathrm{CO}_{2}, \mathrm{H}_{2}$, ammonia, hydrogen sulfide, volatile fatty acids and organic acids like formic, acetic, propionic, butyric acids and acid alcohols through the activities of the (fermentative acidogenic microorganisms (Table 4). Acetic acid $\left(\mathrm{CH}_{3} \mathrm{COOH}\right)$ is the valuable acid in this stage. It serves as a precursor substrate for methane-producing bacteria [18]. 
TABLE 3: Cellulolytic Bacteria IdENTIFIEd In Digestate SAMPles Of UntREATEd AND PRETREATEd Substrates

\begin{tabular}{|c|c|c|c|}
\hline Phylogeny & \multirow{2}{*}{ Species } & \multirow{2}{*}{ Sample } & \multirow{2}{*}{$\%$} \\
\hline Phylum: Firmicutes & & & \\
\hline $\begin{array}{l}\text { Class: Clostridia } \\
\text { Order: Clostridiales } \\
\text { Family: Clostridiaceae }\end{array}$ & $\begin{array}{l}\text { Oxobacter pfennigii } \\
\text { Clostridium hungatei } \\
\text { Clostridium methylpentosum } \\
\text { Clostridium subterminale } \\
\text { Clostridium cellulovorans } \\
\text { Clostridium botulinum } \\
\text { Clostridium celatum } \\
\text { Clostridium sordellii } \\
\text { Clostridium tetani } \\
\text { Clostridium maritimum } \\
\text { Clostridium stercorarium } \\
\text { Clostridium tyrobutyricum } \\
\end{array}$ & $\begin{array}{l}\text { A } \\
\text { A, B } \\
\text { B } \\
\text { A, B } \\
\text { A, B } \\
\text { A } \\
\text { B } \\
\text { B } \\
\text { B } \\
\text { B } \\
\text { A } \\
\text { B }\end{array}$ & $\begin{array}{c}35.92 \\
2.12,0.48 \\
0.50 \\
0.20,1.20 \\
0.1,0.06 \\
0.1 \\
0.1 \\
0.30 \\
0.1 \\
0.71 \\
0.06 \\
1.72 \\
\end{array}$ \\
\hline $\begin{array}{l}\text { Class: Clostridia } \\
\text { Order: Clostridiales } \\
\text { Family: Ruminococcaceae }\end{array}$ & Ruminococcus albus & $\mathrm{B}$ & 7.67 \\
\hline $\begin{array}{l}\text { Class: Clostridia } \\
\text { Order: Thermoanaerobacterales } \\
\text { Family: Incertae sedis }\end{array}$ & $\begin{array}{l}\text { Clostridium ruminantium } \\
\text { Thermoanaerobacter } \\
\text { cellulolyticus }\end{array}$ & $\begin{array}{l}\text { B } \\
\text { B }\end{array}$ & $\begin{array}{l}0.40 \\
0.20\end{array}$ \\
\hline $\begin{array}{l}\text { Class: Bacillus } \\
\text { Order: Bacillales } \\
\text { Family: Bacillaceae }\end{array}$ & $\begin{array}{l}\text { Bacillus koreensis } \\
\text { Bacillus odyssey } \\
\text { Bacillus circulans } \\
\text { Lysinibacillus fusiformis }\end{array}$ & $\begin{array}{l}\mathrm{B} \\
\mathrm{B} \\
\mathrm{B} \\
\mathrm{B}\end{array}$ & $\begin{array}{c}0.20 \\
1.01 \\
0.1 \\
0.1 \\
\end{array}$ \\
\hline $\begin{array}{l}\text { Class: Bacilli } \\
\text { Order: Bacillales } \\
\text { Family: Paenibacillaceae }\end{array}$ & $\begin{array}{l}\text { Paenibacillus } \\
\text { curdlanolyticus }\end{array}$ & B & 0.1 \\
\hline $\begin{array}{l}\text { Class: Bacillus } \\
\text { Order: Bacillales } \\
\text { Family: Planococcaceae }\end{array}$ & Rummeliibacillus stabekisii & B & 0.40 \\
\hline
\end{tabular}

TABLE 4: ACIDOGENIC BACTERIA IDENTIFIED IN DigeStATE SAMPLES OF UNTREATED AND PRETREATED SubSTRATES

\begin{tabular}{|c|c|c|c|}
\hline Phylogeny & Species & Sample & $\%$ \\
\hline $\begin{array}{l}\text { Class: Clostridia } \\
\text { Order: } \\
\text { Thermoanaerobacterales } \\
\text { Family: } \\
\text { Thermoanaerobacteraceae } \\
\end{array}$ & $\begin{array}{l}\text { Thermoanaerobacter } \\
\text { ethanolicus }\end{array}$ & $\mathrm{B}$ & 0.1 \\
\hline $\begin{array}{l}\text { Class: Clostridia } \\
\text { Order: Clostridiales } \\
\text { Family: Clostridiaceae }\end{array}$ & $\begin{array}{l}\text { SMB53 } \\
\text { Clostridium } \\
\text { thermosuccinogenesis } \\
\text { Clostridium acetobutylicum }\end{array}$ & $\begin{array}{l}\text { B } \\
\text { A } \\
\text { A }\end{array}$ & $\begin{array}{l}0.1 \\
0.06 \\
0.06\end{array}$ \\
\hline $\begin{array}{l}\text { Class: Clostridia } \\
\text { Order: Clostridiales } \\
\text { Family: Oscillospiraceae }\end{array}$ & Oscillibacter valericigenes & B & 0.01 \\
\hline $\begin{array}{l}\text { Class: Bacillus } \\
\text { Order: Bacillales } \\
\text { Family: Planococcaceae } \\
\end{array}$ & Kurthia huakuii & B & 0.1 \\
\hline $\begin{array}{l}\text { Class: Bacilli } \\
\text { Order: Lactobacillales } \\
\text { Family: Lactobacillaceae }\end{array}$ & $\begin{array}{l}\text { Lactobacillus delbrueckii } \\
\text { Lactobacillus zymea } \\
\text { Lactobacillus coleohominis } \\
\text { Lactobacillus mucosae } \\
\text { Lactobacillus manihotivorans } \\
\text { Lactobacillus acidophilus } \\
\end{array}$ & $\begin{array}{l}\text { B } \\
\text { A } \\
\text { A } \\
\text { A } \\
\text { A } \\
\text { A }\end{array}$ & \begin{tabular}{c|}
0.1 \\
4.06 \\
1.37 \\
0.36 \\
0.36 \\
8.91 \\
\end{tabular} \\
\hline $\begin{array}{l}\text { Class: Bacillus } \\
\text { Order: Bacillales } \\
\text { Family: Bacillaceae }\end{array}$ & Lysinibacillus massiliensis & B & 0.1 \\
\hline $\begin{array}{l}\text { Class: Actinobacteria } \\
\text { Order: Actinomycetales } \\
\text { Family: Micrococcaceae }\end{array}$ & Arthrobacter castelli & A, B & $0.06,0.1$ \\
\hline $\begin{array}{l}\text { Class: GammaIproteobacteria } \\
\text { Order: Xanthomonadales } \\
\text { Family: Xanthomonadaceae } \\
\end{array}$ & Stenotrophomonas maltophilia & A & 0.12 \\
\hline $\begin{array}{l}\text { Class: Gammaproteobacteria } \\
\text { Order: Enterobacterales } \\
\text { Family: Yersiniaceae } \\
\end{array}$ & Serratia ureolytica & A & 0.06 \\
\hline $\begin{array}{l}\text { Class: Gammaproteobacteria } \\
\text { Order: Pseudomonadales } \\
\text { Family: Moraxellaceae }\end{array}$ & Acinetobacter rhizosphaerae & A & 0.06 \\
\hline $\begin{array}{l}\text { Class: Gammaproteobacteria } \\
\text { Order: Enterobacterales } \\
\text { Family: Enterobacteriaceae }\end{array}$ & Shigella sonnei & A & 0.06 \\
\hline
\end{tabular}

\section{Acetogenesis}

This stage consists of a two-way reaction with the release of hydrogen $\left(\mathrm{H}_{2}\right)$. Acidic byproducts are transformed to acetate $\left(\mathrm{CH}_{3} \mathrm{COO}^{-}\right)$and hydrogen $\left(\mathrm{H}_{2}\right)$ in the first reaction. These metabolic intermediates are subsequently utilized by methanogens in the succeeding stage of anaerobic digestion 
with the release of $\mathrm{H}_{2}$. This reaction displays noxious effects on the acetogenic microorganisms [19], [20]. To circumvent this effect, a balance between acetogens and methanogens is essential to consume $\mathrm{H}_{2}$ molecule generated in the process. Again, the acid forming step of AD process is very critical (highlighting the biogas production efficiency of any substrate) and accounts for nearly $70 \%$ of $\mathrm{CH}_{4}$ produced through the reduction of acetate, a key intermediate of the $\mathrm{AD}$ process [19]. It is noteworthy to mention that the volatile fatty acids and short chain fatty acids formed in the preceding stage of $\mathrm{AD}$ can be further converted to $\mathrm{CH}_{3} \mathrm{COOH}, \mathrm{CO}_{2}$ and $\mathrm{H}_{2}$ by obligate hydrogen-producing acetogenic bacteria [21]. Examples of acetogenic bacteria are members of the class Clostridia (Table 5).

TABLE 5: ACETOGENIC BACTERIA IDENTIFIED IN DigeSTATE SAMPLES OF UNTREATED AND PRETREATED SUBSTRATES

\begin{tabular}{|c|c|c|c|}
\hline Phylogeny & Species & Sample & $\begin{array}{l}\% \text { of } \\
\text { Total }\end{array}$ \\
\hline $\begin{array}{l}\text { Class: Clostridia } \\
\text { Order: Clostridiales } \\
\text { Family: Clostridiaceae }\end{array}$ & $\begin{array}{l}\text { Proteiniclasticum } \\
\text { ruminis }\end{array}$ & B & 0.1 \\
\hline $\begin{array}{l}\text { Class: Clostridia } \\
\text { Order: Clostridiale } \\
\text { Family: Clostridiaceae }\end{array}$ & $\begin{array}{l}\text { Clostridium } \\
\text { tyrobutyricum } \\
\text { Clostridium ljungdahlii }\end{array}$ & $\begin{array}{l}\mathrm{A} \\
\mathrm{A}\end{array}$ & $\begin{array}{c}33.05 \\
0.60\end{array}$ \\
\hline $\begin{array}{l}\text { Class: Clostridia } \\
\text { Order: } \\
\text { Thermoanaerobacterales } \\
\text { Family: } \\
\text { Thermoanaerobacteraceae }\end{array}$ & $\begin{array}{l}\text { Thermacetogenium } \\
\text { phaeum }\end{array}$ & B & 0.1 \\
\hline $\begin{array}{l}\text { Class: Clostridia } \\
\text { Order: Eubacteriales } \\
\text { Family: Oscillospiraceae }\end{array}$ & $\begin{array}{l}\text { Papillibacter } \\
\text { cinnamivorans }\end{array}$ & B & 0.1 \\
\hline $\begin{array}{l}\text { Class: Clostridia } \\
\text { Order: Clostridiales } \\
\text { Family: Ruminococcaceae }\end{array}$ & $\begin{array}{l}\text { Ethanoligenens } \\
\text { harbinense }\end{array}$ & A, B & $\begin{array}{l}29.53 \\
10.60\end{array}$ \\
\hline $\begin{array}{l}\text { Class: Erysipelotrichia } \\
\text { Order: Erysipelotrichales } \\
\text { Family: } \\
\text { Erysipelotrichaceae }\end{array}$ & Turicibacter sanguinis & B & 0.1 \\
\hline $\begin{array}{l}\text { Class: Negativicutes } \\
\text { Order: Selenomonadales } \\
\text { Family: Sporomusaceae }\end{array}$ & $\begin{array}{l}\text { Anaerospora } \\
\text { hongkongensis }\end{array}$ & B & 0.1 \\
\hline $\begin{array}{l}\text { Class: Bacilli } \\
\text { Order: Lactobacillales } \\
\text { Family: Lactobacillaceae }\end{array}$ & Pediococcus damnosus & A & 0.36 \\
\hline
\end{tabular}

\section{Methanogenesis}

This is considered the last step in anaerobic digestion process. Here, carbondioxide $\left(\mathrm{CO}_{2}\right)$ and methane $\left(\mathrm{CH}_{4}\right)$ are produced from the conversion of acetic acid $\left(\mathrm{CH}_{3} \mathrm{COOH}\right)$ and hydrogen $\left(\mathrm{H}_{2}\right)$ by the action of microorganisms Methanogenic microorganisms (Table 6) are responsible for this conversion and the process is called methanogenesis. These organisms are strict anaerobes [16], [22]. The reaction which takes place during methanogenesis involves the following: firstly, acetate is converted to methane and carbondioxide which is further reduced to methane. The reduction is achieved by hydrogen gas formed in the acidogenesis and acetogenesis stages producing methane gas, an integral component of biogas by the decarboxylation of ethanol [16].

In literature, six main pathways of substrate conversion for methane production have been documented. The foremost substrates that are utilized in the methanogenesis phase include acetic acid $\left(\mathrm{CH}_{3} \mathrm{COOH}\right)$, methanoic acid $(\mathrm{HCOOH})$, carbon(IV)oxide $\left(\mathrm{CO}_{2}\right)$, dimethyl sulfate
$\left.\left(\left(\mathrm{CH}_{3}\right)_{2} \mathrm{SO}_{4}\right)\right)$, methanol $\left(\mathrm{CH}_{3} \mathrm{OH}\right)$, and methylamine $\left(\mathrm{CH}_{3} \mathrm{NH}_{2}\right)$ [23].

TABLE 6: METHANOGENIC ARCHAEA IDENTIFIED IN DIGESTATE SAMPLES OF UNTREATED AND PRETREATED SUBSTRATE

\begin{tabular}{llcc}
\multicolumn{1}{c}{ Phylogeny } & \multicolumn{1}{c}{ Species } & Sample & $\begin{array}{c}\% \text { of } \\
\text { Total }\end{array}$ \\
\hline $\begin{array}{l}\text { Class: Methanomicrobia } \\
\begin{array}{l}\text { Order: Methanomicrobiales } \\
\text { Family: Methanospirillaceae }\end{array}\end{array}$ & $\begin{array}{l}\text { Methanospirillum } \\
\text { hungatei }\end{array}$ & A, B & $\begin{array}{c}0.30, \\
0.50\end{array}$ \\
\hline $\begin{array}{l}\text { Class: Methanomicrobia } \\
\begin{array}{l}\text { Order: Methanosarcinales } \\
\text { Family: Methanosaetaceae }\end{array}\end{array}$ & $\begin{array}{l}\text { Methanosaeta } \\
\text { concilii }\end{array}$ & A & 0.05 \\
\hline
\end{tabular}

\section{B. Taxonomic Composition of Anaerobic} Microorganisms Involved in Biogas Production Generated from Clone Library 16S-DNA Metagenomic Sequences

In culture-dependent techniques, usually a little segment of the existing microbial species residing in a bioreactor can be cultivated and isolated. In contrast, non-culturedependent (DNA-based) molecular techniques can serve as indispensable tool to explore and reveal the entire composition of microbes in a digester [24].

In this study, full-length 16S-DNA amplification, SMRTbell ${ }^{\circledR}$ library preparation and metagenomics sequencing methods, were deployed to ascertain bacterial (and archaeal) communities in biogas digesters. Environmental gene tags (EGTs) and 16S-DNA libraries were consequently constructed [25]-[28].

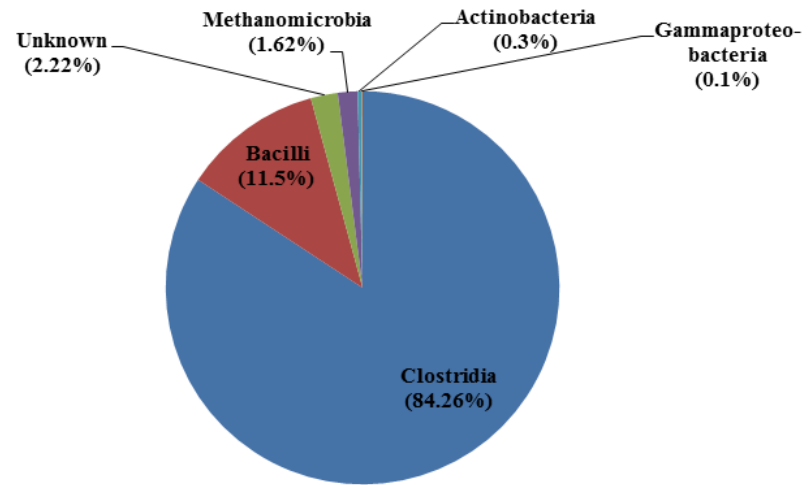

Fig. 1 a. Phylogenetic class indicating the percentage of unknown microorganisms in untreated digestate after metagenomic analysis.

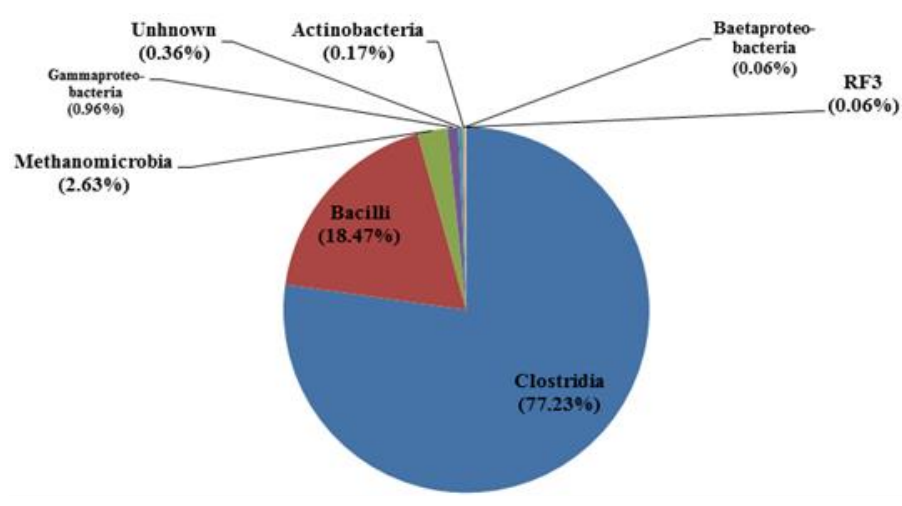

Fig. 1 b. Phylogenetic class indicating the percentage of unknown microorganisms in pretreated digestate after metagenomic analysis. 
C. Biochemistry and Metabolism of Bacterial and Archaeal Clone Library Encountered in the Current Study

Cellulolytic bacteria in Firmicutes, includes Oxobacter pfennigii and Ruminococcus albus. Oxobacter pfennigii breaks down methoxylated aromatic compounds to butyrate but does not use sugars nor amino acids as its sources of energy [29]. Moreover, it can reduce carbon monoxide and produce acetate and butyrate [29]. Albeit Oxobacter pfennigii does not obtain its energy from sugars it however harbours genes coding for proteins during glycolysis. Again, its genome also lacks the phosphotransferase system - PTS (phosphoenolpyruvate [PEP]: carbohydrate phosphotransferase system) and the respective gene products of the glycolysis probably serve for gluconeogenesis pathway solely. With regard to its autotrophic and acetogenic nature, of $O$. pfennigii has been found to encode genes of the methyl- and carbonyl-divisions of the Wood-Ljungdahl pathway as well as those of the Rhodobacter nitrogen fixation (Rnf) complex [30].

Ruminococcus albus produces ethanol and $\mathrm{CO}_{2}$ as its major fermentation products, along with lesser amounts of acetate, formate, and $\mathrm{H}_{2}$ [31]. An enormous range of enzymes that participate in the metabolism of several sugars is possessed by acid-loving Lactobacilli. These sugars can be categorized according to their level of assimilation as follows: hexoses (e.g. glucose, mannose, galactose, fructose) and pentose (e.g. arabinose and xylose), as well as other types of sugars [32]-[34]. Depending on the end product of the fermentation process, lactobacilli are broadly grouped into two categories as homofermentative and heterofermentative, with the latter further divided into facultative and obligate. Since they constantly produce only from glycolysis greater than $(>85 \%)$ lactic acid, homofermentative lactobacilli are wholly grouped as obligate. This is achieved by means of the EmbdenMeyerhof-Parnes (EMP) glycolytic pathway from the assimilation of hexoses. The hexose sugars are transported by enzymes of the membrane called permeases, ABC (ATP Binding Cassette) transporters and phosphoenolpyruvate: carbohydrate phosphotransferase (PEP: PTS). This metabolism is typified by the splitting of 1,6-diphosphate sugar (e.g. fructose) into two phosphates trioses, that are quickly converted to lactic acid [35]-[37]. By means of phosphogluconate and phosphoketolase pathways, members of Lactobacilli categorized in the obligate heterofermentative subgroup conversely generate lactic acid, acetic acid, ethanol and $\mathrm{CO}_{2}$ through the anaerobic conversion of six carbon sugars to produce lactic acid, acetic acid, ethanol and by the fermentation of five carbon sugars to lactic acid, acetic acid, ethanol without $\mathrm{CO}_{2}$. They also lack the enzyme aldolase (fructose-1,6-diphosphatase) - a crucial enzyme of the glycolytic pathway. But present only in the pentose pathway is the phosphoketolase enzyme [37].

Acetogenic anaerobe Clostridium tyrobutyricum produces butyric acid, $\mathrm{CO}_{2}$ and $\mathrm{H}_{2}$ from lactic acid. A summary of the metabolic pathway in Clostridium tyrobutyricum involving shotgun proteomics proposed that the phosphotransferase system (PTS) is mainly used for the assimilation of glucose by Clostridium tyrobutyricum [38].
Clostridium tyrobutyricum is found to catabolize glucose into pyruvate mainly via glycolysis. Genes related to the Entner-Doudoroff pathway and the oxidative branch of the pentose phosphate (PP) pathway are not present [38]. Like other species of Clostridium, $C$. tyrobutyricum converts pyruvate into acetyl-CoA and carbondioxide using the enzyme pyruvate:ferredoxin oxidoreductase. In addition, butyric acid production in Clostridium tyrobutyricum KCTC 5387 (ATCC 25755) is governed by the action of butyrate:acetate CoA transferase enzyme and not phosphotransbutyrylase (PTB) and butyrate kinase (BK) [38].

Ethanoligenens are typically anaerobic fermentative hydrogen-producing bacteria. Its products of fermentation can further be consumed as energy source $\left(\mathrm{H}_{2}\right.$ and ethanol) or as an essential harbinger (acetate) for cogeneration of methane and electric power [39]-[43].

Generally, the relative abundance of energy metabolism genes and carbohydrate metabolism genes contributes to the production of $\mathrm{H}_{2}$-ethanol by Ethanoligenens harbinense strains. The genes coding for the fundamental enzyme [FeFe]-hydrogenases $\left(\mathrm{H}_{2}\right.$ ases $)$ critical for hydrogen evolution has also been reported in the genome of Ethanoligenens harbinense [44]. Other genes include those coding for essential enzymes (acetaldehyde dehydrogenase/alcohol dehydrogenase proteins), and have been implicated in metabolism and synthesis alcohol [44].

Methanogenesis in Methanospirillum hungatei begins with the initiation reaction of transforming of acetate to acetyl-CoA [45], [46] using the enzyme acetate kinase and phosphoo-transacetylase [46]. Acetyl-CoA generated at the cost of one ATP via acetylphosphate is hydrolysed to adenosine monophosphate (ADP) and inorganic phosphate (Pi) [46]. Acetyl-CoA produced after acetate transformation, is cleaved at two points approximately at the oxidation level of methanol (methyl group) into Ct-units and another at the oxidation level of CO (carbonyl group) [45]. The cleavage of the carbon-carbon bond and consequent oxidation of the carbonyl group are catalyzed possibly by a similar enzyme: carbon monoxide (CO) dehydrogenase [46]. This leads to the formation of methyl group that is then reduced to $\mathrm{CH}_{4}$. The electrons for this methyl $\left(\mathrm{CH}_{3}\right)$ reduction originates from carbon monoxide oxidation [46]. During this reduction, coenzyme $M$ receives methyl group of acetylCoA as accelerated by some methyl-transferases enzymes [45], [47]. In Methanosarcina, enzymes containing corrihold and tetrahydromethanopterin are associated with this transfer [47]. The final step in biomethanation occurs when methyl-coenzyme $\mathrm{M}$ is reduced to $\mathrm{CH}_{4}$ [48] which is promoted by the enzyme methyl-CoM methylreductase [46], [48], [49].

\section{CONCLUSION}

Anaerobic codigestion of pretreated coconut husk fiber/pineapple floret/banana stem and monodigestion of untreated banana stem displayed improved biogas productivity and efficient total solids removal. This established the potential for use of the agro-lignocellulosic 
waste under evaluation as promising substrates for biomethanation. Metagenomic analysis of samples revealed great diversity and rich assemblage of bacterial and archaeal communities in digestate samples. The bacterial library was predominantly fermentative heterotrophs and (re)presented hydrolytic and fermentative bacteria as main organisms associated with anaerobic degradation of coconut husk fiber/pineapple floret/banana stem. Comparatively, anaerobic syntrophic propionate and aromatic compounds degrading bacteria were additionally observed in magnitudes higher than hydrolytic and fermenting bacteria whereas hydrogenotrophic methanogenic bacteria were more dominant than their aceticlastic methane-producing counterparts in the anaerobic digestion involving lignocellulosic biomass.

\section{ACKNOWLEDGMENT}

The authors would like to appreciate the efforts of anonymous reviewers in improving the quality of the paper. We are also grateful to Damilola Kareem (Laboratory Manager), John Akanbi (Bioinformatician) and Oluokun Emmanuel (Research Support Officer) of Bioinformatics Services, Ibadan, Nigeria for performing the metagenomics analyses reported in this work.

\section{REFERENCES}

[1] Ndubuisi-Nnaji, U. U., Ofon, U. A., Asamudo, N. U. and Ekong, V. M. (2020a). Enhanced biogas and biofertilizer production from anaerobic codigestion of harvest residues and goat manure. Journal of Scientific Research and Reports, 26(3): 1-13.

[2] Eduok, S., John, O., Ita, B., Inyang, E and Coulon, F. (2018). Enhanced biogas production from anaerobic co-digestion of lignocellulosic biomass and poultry faeces using source separated human urine as buffering agent. Frontiers in Environmental Science, 6: 67. doi: 10.3389/fenvs.2018.00067.

[3] Ndubuisi-Nnaji, U. U., Ofon, U. A., Ekponne, N. I and Offiong, N. O. (2020b). Improved biofertilizer properties of digestate from codigestion of brewer's spent grain and palm oil mill effluent by manure supplementation. Sustainable Environment Research, 30(1): $1-11$.

[4] Dinuccio, E., Balsari, P., Gioelli, F and Menardo, S. (2010) Evaluation of the biogas productivity potential of some Italian agroindustrial biomasses. Bioresource Technology, 101(10): 3780-3783. doi: 10.1016/j.biortech.2009.12.113.

[5] Ndubuisi-Nnaji, U. U., Ofon, U. A., Inyang-Enin, A. O and Georgina N. Ananso. (2020c). Enhanced Biogas Production from Anaerobic Codigestion of Lignocellulosic Waste for Efficient Bioenergy Utilization in Heating and Combustion Engine. Advances in Research, 21(1): 11-21. DOI: 10.9734/AIR/2020/v21i130178.

[6] Qiao, J. T., Qiu, Y. L., Yuan, X. Z., Shi, X. S., Xu, X. H., \& Guo, R. B. (2013). Molecular characterization of bacterial and archaeal communities in a full-scale anaerobic reactor treating corn straw. Bioresource Technology, 143: 512-518.

[7] Angelidaki, I., Alves, M., Bolzonella, D., Borzacconi, L., Campos, J. L., Guwy, A. J., Kalyuzhnyi, S., Jenicel, P. and van Lier, J. B. (2009). Defining the biomethane potential (BMP) of solid organic wastes and energy crops: a proposed protocol for batch assays. Water Science and Technology, 59(5): 927-934.

[8] Orhorhoro, E. K., Ebunilo, P. O. and Sadjere, G. E. (2017) Experimental determination of effect of total solids (TS) and volatile solids (VS) on biogas yield. American Journal of Modern Energy. 3: 131-135. doi: 10.11648/j.ajme.20170306.13

[9] Gabor, E., Liebeton, K., Niehaus, F., Eck, J. and Lorenz, P. (2016) Updating the metagenomics toolbox. Journal of Biotechnology, 2 201-206.
[10] Atawodi, S. E., Atawodi, J. C. and Dzikwi, A. A. (2010). Polymerase chain reaction: theory, practical and application: a review. Sahel Medical Journal, 13(2): 54-63.

[11] Sekiguchi, Y., Kamagata, Y., Syutsubo, K., Ohashi, A., Harada, H and Nakamura, K. (1998). Phylogenetic diversity of mesophilic and thermophilic granular sludges determined by $16 \mathrm{~S}$ rRNA gene analysis. Microbiology, 144: 2655-2665.

[12] Cha, G. C., Chung, H. K. and Kim, D. J. (2001). Characteristics of temperature change on the substrate degradation and bacterial population in one-phase and two-phase anaerobic digestion Environmental Engineering Resources, 6: 99-108.

[13] Demirel, B. and Scherer, P. (2008). The roles of acetotrophic and hydrogenotrophic methanogens during anaerobic conversion of biomass to methane: A review. Review in Environmental Science and Biotechnology, 7: 173-190.

[14] Franke-Whittle, I. H., Goberna, M., Pfister, V and Insam, H. (2009). Design and development of the anaerochip microarray for investigation of methanogenic communities. Journal of Microbiological Methods, 79: 279-288.

[15] Wilkins, D., Rao, S., Lu, X. and Lee, P. K. H. (2015). Effects of sludge inoculum and organic feedstock on active microbial communities and methane yield during anaerobic digestion. Frontiers in Microbiology, 6: $1114-1124$.

[16] Anukam, A., Mohammadi, A., Naqvi, M. and Granström, K. (2019). A review of the chemistry of anaerobic digestion: Methods of accelerating and optimizing process efficiency. MDPI Processes, 7(504): 1-19. doi:10.3390/pr7080504.

[17] Lynd, L. R., Weimer, P. J., van Zyl, W. H. and Pretorius, I. S (2002). Microbial cellulose utilization: fundamentals and biotechnology. Microbiology and Molecular Biology Review, 63(6) 506-577.

[18] Kovács, E., Wirth, R., Maróti, G., Bagi, Z., Rákhely, G. and Kovács, K. L. (2013). Biogas production from protein-rich biomass: fedbatch anaerobic fermentation of casein and of pig blood and associated changes in microbial community composition. PLOS ONE 8(10): 1-18.

[19] Chen, Y. and Schink, B. (1997). Energetics of syntrophic cooperation in methanogenic degradation. Journal of Microbiology and Molecular Biology Review, 61: 262-280.

[20] De Bok, F. A., Harmsen, H. J., Plugge, C. M., de Vries, M. C., Akkermans, A. D., de Vos, W. M and Stams, A. J. (2005). The first true obligately syntrophic propionate-oxidizing bacterium, Pelotomaculum schinkii sp. nov., co-cultured with Methanospirillum hungatei, and emended description of the genus Pelotomaculum. International Journal of Systematic Evolution and Microbiology, 55: 1697-1703.

[21] Singleton, P. (2006). Acetogenesis: In Dictionary of Microbiology and Molecular Biology, 3rd ed.; John Wiley: Hoboken, New Jersey, USA, 2006; ISBN 978-0-470-03545-0.

[22] Verma, S. (2002). Anaerobic Digestion of Biodegradable Organics in Municipal Solid Wastes. Master's Thesis, Columbia University, New York, USA, pp. 1-56.

[23] Slonczewski, J. L and Foster, J. W. (2014). Microbiology: An Evolving Science 3; W.W. Norton and Company: New York, USA, $51 \mathrm{p}$.

[24] Zverlov, V. V., Ko"ck, D. E. and Schwarz, W. H. (2015). The role of cellulose-hydrolyzing bacteria in the production of biogas from plant biomass. Microorganisms in Biorefineries, Microbiology Monographs, 26: 335-361. doi: 10.1007/978-3-662-45209-7_12.

[25] Krause, L., Diaz, N. N., Edwards, R. A., Gartemann, K. H., Kro"meke, H., Neuwger, H., Pu"hler, A., Runte, K. J., Schlu"ter, A Stoye, J., Szczepanowski, R., Tauch, A and Goesmann, A. (2008). Taxonomic composition and gene content of a methane producing microbial community isolated from a biogas reactor. Journal of Biotechnology, 136: 91-101.

[26] Schlüter, A., Bekel, T., Diaz, N. N., Dondrup, M., Eichenlaub, R., Gartemann, K. H., Krahn, I., Krause, L., Kro"meke, H., Kruse, O. Mussgnug, J. H., Neuweger, H., Niehaus, K., Pu"hler, A., Runte, K J., Szczepanpwski, R., Tauch, A., Tilker, A., Vieho"ver, P and Goessmann, A. (2008). The metagenome of a biogas-producing microbial community of a production-scale biogas plant fermente analyzed by the 454-pyrosequencing technology. Journal of Biotechnology, 1(136): 77-90.

[27] Kröber, M. S., Bekel, T., Diaz, N and Goesman, A. I (2009). Phylogenetic characterization of a biogas plant microbial community integrating clone library $16 \mathrm{~S}-\mathrm{rDNA}$ sequences and metagenome sequence data obtained by 454-pyrosequencing. Journal of Biotechnology, 142(1):38-49. doi: 10.1016/j.jbiotec.2009.02.010. 
[28] Wirth, R., Kovacs, E., Maroti, G., Bagi, Z., Rakhely, G and Kovacs, K. L. (2012) Characterization of a biogas producing microbial community by short-read next generation DNA sequencing. Biotechnology for Biofuels, 5(1): 41.

[29] Krumholz, L. R and Bryant, M. P. (1985). Clostridium pfennigii sp. nov. uses methoxyl groups of monobenzenoids and produces butyrate. International Journal of Systematic and Evolutionary Microbiology, 35: 454-456. doi:10.1099/00207713-35-4-454.

[30] Bengelsdorf, F. R., Poehlein, A., Schiel-Bengelsdorf, B., Daniel, R and Dürre, P. (2015). Genome sequence of the acetogenic bacterium Oxobacter pfennigii DSM 3222T. Genome Announcement, 3(6): e01408-15. doi:10.1128/genomeA.01408-15.

[31] Pavlostathis, S. G., Miller, T. L and Wolin, M. J. (1988) Fermentation of insoluble cellulose by continuous cultures of Ruminococcus albus. Applied Environmental Microbiology, 54 2655-2659.

[32] El Kaoutari, A., Armougon, F., Gordon, J. I., Raoult, D and Henrissat, B. (2013). The abundance and variety of carbohydrate active enzymes in the human gut microbiota. National Review in Microbiology, 11(7): 497-504.

[33] Drissi, F., Raoult, D and Merhej, V. (2016). Metabolic role of Lactobacilli in weight modification in humans and animals. Microbial Pathogenesis, 106: 182-194.doi: 10.1016/j.micpath.2016.03.006.

[34] Amanda, M., Lucas, S., Iranildo, F and Valmir, L. (2017) Metabolism and physiology of Lactobacilli: a review. Journal of Environmental Analysis and Progress, 2(2): 125-136. doi: 10.24221/jeap.2.2.2017.1202.115-124.

[35] Pessione, E. (2012). Lactic acid bacteria contribution to gut microbiota complexity: lights and shadows. Frontiers in Cell Infection Microbiology, 2(86): 1-15. doi.org/10.3389/fcimb.2012.00086.

[36] Salvetti, E., Torriani, S and Felis, G. E. (2012). The genus Lactobacillus: a taxonomic update. Probiotics Antimicrobial Proteins, 4(4): 217-226. doi:10.1007/s12602-012-9117-8

[37] Abdel-Rahman, M. A., TAshton, Y and Sonomoto, K. (2013). Recent advances in lactic acid production by microbial fermentation processes. Biotechnology Advancement, 31(6): 877-902. doi:10.1016/j.biotechadv.2013.04.00.

[38] Lee, J., Jang, Y. S., Han, M. J., Kim, J. Y and Lee, S. Y. (2016) Deciphering Clostridium tyrobutyricum metabolism based on the whole-genome sequence and proteome analyses. American Society for Microbiology, 7(3): e00743-16. doi: 10.1128/mBio.00743-16.

[39] Lee, H. S., Vermaas, W. F and Rittmann, B. E. (2010). Biological hydrogen production: prospects and challenges. Trends in Biotechnology, 28 (5): 262-271.doi: 10.1016/j.tibtech.2010.01.007.

[40] Meherkotay, S and Das, D. (2008). Biohydrogen as a renewable energy resource-prospects and potentials. International Journal Hydrogen Energy, 33 (1): 258-263. doi: 10.1016/j.ijhydene.2007.07.031.

[41] Christy, P. M., Gopinath, L. R and Divya, D. (2014). A review on anaerobic decomposition and enhancement of biogas production through enzymes and microorganisms. Renewable and Sustainable Energy Reviews, 34 (6): 167-173. doi: 10.1016/j.rser.2014.03.010.

[42] Lu, L. and Ren, Z. J. (2016). Microbial electrolysis cells for waste biorefinery: a state of the art review. Bioresource Technology, 215 254-264. Dionisi, D. and Silva, I.M.O. (2016). Production of ethanol, organic acids and hydrogen: an opportunity for mixed culture biotechnology? Reviews in Environmental Science and Biotechnology, 15 (2): 213-242. doi.org/10.1007/s11157-016-9393-

[43] Lu, Q., Yi, J. and Yang, D. (2016). Comparative analysis of performance and microbial characteristics between high-solid and low-solid anaerobic digestion of sewage sludge under mesophilic conditions. Journal of Microbiology and Biotechnology, 26(1): 110 119 .

[44] Li, Z., Liu, B., Cui, H., Ding, J., Li, H., Xie, G., Ren, N and Xing, D (2019). The complete genome sequence of Ethanoligenens harbinense reveals the metabolic pathway of acetate-ethanol fermentation: A novel understanding of the principles of anaerobic biotechnology. Environment International, 131: 105053. https://doi.org/10.1016/j.envint.2019.105053.

[45] Thauer, R. K., Zinkhan-Mi11er, D and Spormann, A. M. (1989). Biochemistry of acetate catabolism in anaerobic chemotrophic bacteria. Annual Review in Microbiology, 43: 43-67.

46] Jetten, S. M. M., Stams, J. M. A. and Zehnder, J. B. A. (1992). Methanogenesis from acetate: a comparison of the acetate metabolism in Methanothrix soehngenii and Methanosarcina spp.
Federation of European Microbiological Societies, 88(4): 181-198. doi.org/10.1111/j.1574-6968.1992.tb04987.x.

[47] Kengen, S. W. M., Daas, P. J. H., Duits, E. F. G., Keltjens, J. T., Van der Drift, C and Vogeis, G. D. (1992). Isolation of a 5hydroxybenzimidazolyl cobamide-containing enzyme involved in the metbyltetrahydromethanopterin: coenzyme $\mathrm{M}$ metbyltransferase reaction in Methanobacterium thermoautotmphicum. Biochimica et Biophysica. Acta, 1118: 249-260. doi:10.1016/0167-4838(92)90282i.

[48] Dimarco, A. A., Bobik, T. A. and Wolfe, R. S. (1990). Unusual coenzymes of methanogenesis. Annual Review in Biochemistry, 59. 355-394. doi.org/10.1146/annurev.bi.59.070190.002035.

[49] Jablonski, P. E and Ferry, J. G. (1991). Purification and properties of methyl coenzyme $M$ methylreductase from acetate-grown Methanosarcina thermophila. Journal of Bacteriology, 173(8): 24812487. doi: 10.1128/jb.173.8.2481-2487.1991.

Dr Uduak Ndubuisi-Nnaji holds a B.Sc (Microbiology) from the University of Calabar and an M.Sc (Industrial Microbiology) and Ph.D (Environmental Microbiology \& Biotechnology) from the unique University of Port Harcourt, Nigeria. She has undertaken several scientific researches in Microbiology and Biotechnology including but not limited to identifying fertilizer utilizing organisms in tropical agro soils using cultural and molecular techniques with a potential for their use in remediation and ecorestoration of soil health, response of different soil organisms to environmental stress. She is also involved in researches aimed at sustainable use of natural resources as well as turning waste into wealth in Environmental Biotechnology. She is a scholar with many publications in reputable local and international journals. A recipient of several honours and awards including best graduating student (B.Sc \& M.Sc) and the National Association of Microbiology Students (NAMS) award of excellence. She is a member of many professional bodies (OWSD, ASM, NSM, NISEB, RAESON, NES, NIFST) and has travelled widely to attend conferences and made several presentations. She is presently an Assistant Professor in the Department of Microbiology, University of Uyo and is happily married with children.

Inyang-Enin Ata presently works as a Senior Research and Development (R\&D) Officer with the Building Research Department of the 'Nigerian Building and Road Research Institute (NBRRI)' - an agency under the auspices of Nigeria's Federal Ministry of Science \& Technology, based in Abuja, Nigeria. He was born on the 15th of November, 1983 at Ebute Metta /Yaba Local Government Area of Lagos State, Nigeria. In 2005, he obtained a Bachelor of Science (B.Sc) degree in microbiology and brewing science in Enugu State University of Science and Technology, Agbani, Enugu State, Nigeria.

At present, he has published a few journal articles and presented technical research papers in international conferences. Two of his publications are underlisted.

[1] "An Investigation into Noxious Circulation of Indoor Molds in Residential Apartments: A Case Study of Uturu Hostels, Abia State, Nigeria", (International Journal of Engineering Research and Advanced Technology, 2019, 5(4): 1-8. DOI: 10.31695/IJERAT.2019.3408)

[2] "Enhanced Biogas Production from Anaerobic Codigestion of Lignocellulosic Waste for Efficient Bioenergy Utilization in Heating and Combustion Engine", (Advances in Research, 2020, 21(1): 11-21. DOI: 10.9734/AIR/2020/v21i130178)

$\mathrm{Mr}$ Inyang-Enin Ata is a registered member of "Renewable and Alternative Energy Society of Nigeria" (RAESON). His core research interest Includes Environmental sciences and Energy systems (renewable and non-renewable).

Utibe A. Ofon is a native of Akwa Ibom State, Nigeria where he obtained his Bachelor and Masters of Science degrees (in the field of Environmental Microbiology) from the prestigious University of Uyo (Nigeria) in 2012 and 2019 respectively.

$\mathrm{He}$ is currently teaching, undertaking research supervision for undergraduate students in the Department of Microbiology, University of Uyo and has published several research articles to his credit in reputable peer-reviewed international and local journals not to mention his numerous paper presentation at scientific fora. His research interests include; Environmental Microbiology and Biotechnology, Biomass-to-Biofue Technology, Renewable Energy and Bioremediation of xenobiotic compounds.

Mr Ofon is an active Global Outreach member of the American Society for Microbiology (ASM), Nigerian Society for Microbiology (NSM), Renewable and Alternative Energy Society of Nigeria (RAESON) and Society for Experimental Biology of Nigeria (NISEB). 
Osagie Ibhadode presently works as a Senior Research and Development (R\&D) Engineer with the Building Research Department of the 'Nigerian Building and Road Research Institute (NBRRI)' — an agency under the auspices of Nigeria's Federal Ministry of Science \& Technology, based in Abuja, Nigeria. He was born on the 19th of June, 1982 at BeninCity in Edo State, Nigeria. In 2006, he obtained a Bachelor of Engineering (B. Eng.) degree in mechanical engineering from Ambrose Alli University, Ekpoma, Edo State, Nigeria.

Before joining the service of NBRRI, between 2007 and 2009, he practiced Occupational Safety, Health and Environment (SHE), and Project Engineering and Management, while working as a SHE-Officer, Field Engineer, Project Engineer, and Project Manager at the 'Hafalix Nigeria Limited', an indigenous Engineering, Construction, Maritime \& Logistics Company based in Port-Harcourt, Nigeria. While there, he was involved in the construction of bridges, platforms, jetties, buildings and roads; and took part in river dredging operations. Presently, he has published at least twenty-two (22) scholarly research articles in learned journals online and presented several technical research papers in major international conferences.

Three of his publications are underlisted.

[1] "Assessment of noise-levels of generator-sets in seven cities of South-Southern Nigeria", (African Journal of Science, Technology, Innovation and Development, Taylor \& Francis and NISC Pty Ltd, 2018, 125-135. DOI: 10.1080/20421338.2017.1400711).

[2] "An evaluation of classroom-illumination: a critical requirement for effective designing and construction of naturally-illuminated schools in Nigeria", (Progress in Industrial Ecology - An International Journal, Inderscience Enterprises Ltd., 2019, 13(4), 342-372. DOI: 10.1504/PIE.2019.102849).

[3] "Thermophysical, Electrical and Mechanical Characterizations of Normal and Special Concretes: A Holistic-Empirical Investigation for Prequalification and Quality-Control of Concrete", (J. Phys.: Conf. Ser., IOP Publishing, 2019, Article ID No.: 1378 (2019) 042100. DOI: 10.1088/17426596/1378/4/042100).

Engr Osagie Ibhadode is a registered member of the 'Council for the Regulation of Engineering in Nigeria (COREN)', the 'Nigerian Society of Engineers (NSE)', 'Nigerian Institute of Mechanical Engineers (NIMechE)' and the 'Nigerian Institute of Management (NIM)-Chartered'. His core research interests include Environmental science and engineering (indoor, outdoor- and the built-environment), Material science and engineering (conventional and new materials), Energy systems (renewable and nonrenewable), Eco-green solutions/smart technologies/emerging trends and Engineering analyses \& modelling etc. 